\title{
In vitro Callus Induction of Green Bamboo
}

\author{
A. S. Mali", N. S. Chavan and N. R. Chavan \\ MGM College of Agricultural Biotechnology (CABT), Vasantrao Naik Marathwada Krishi \\ Vidyapeeth, Gandheli, Aurangabad-431003, Maharashtra, India \\ *Corresponding author
}

\section{A B S T R A C T}

\section{Keywords}

Bamboo, Plant tissue Culture, Callus, 2,4Dichlorophenoxyac etic acid.

\section{Article Info}

Accepted:

07 September 2020

Available Online:

10 October 2020
Bamboo farming is one of the most promising business in India due to high productivity and assured yield under adverse conditions. The increasing demand of bamboo plantlets can be not be met by traditional cultivation methods. Plant tissue culture techniques have potential for producing large number of healthy plantlets for ever-growing demand. Hence for in vitro culture techniques induction of callus is necessary which can be further used for organogenesis and somatic embryogenesis. The present study demonstrates a simple and efficient method for callus induction of Bamboo. The leaf, node and seed are used as explants for induction of callus. These explants were subjected to sterilization treatment and it is found that Tween -20 , bavistin and ethanol are sufficient for proper sterilization of explants. Then these explants were subjected to various concentrations of growth hormone 2,4-Dichlorophenoxyacetic acid (2,4-D) added in Murashige and Skoog Media. It was concluded that the seeds are suitable explants for rapid induction of callus. Then the various concentration of 0 to $8 \mathrm{mg} / \mathrm{lit}$ of 2,4-Dichlorophenoxyacetic acid was used and it was observed that $5 \mathrm{mg} / \mathrm{lit}$ concentration is best suited for growth of callus under in vitro condition when all other parameters are kept constant.

\section{Introduction}

Bamboo is a fast-growing plant. Bamboo plants distribute from tropical to temperate zones of Southeast Asia and they provide useful resource for local economies (Chang et al., 1991 and Chang et al., 1997). Bamboo firstly originated in China over 5000 years ago. Han Dynasty (206 to 221 BC) starts the use of bamboo to make paper and books. There are 1000 species and 91 genera of bamboo. Dendrocalamus strictus, Bambusa arundinacea and Bambusa vulgaris are among the important species found in India.
In bamboo genetic resource India is second largest after China. India's natural resources of bamboo, consisting of a large number of species, constituents one of the world's largest reserves of this commodity. In India out of total forest area of 75 million hectares bamboos, natural and planted, occupy 10 million hectares. About 9.5 million tones is the annual production of bamboo in India (Varmah et al., 1981).

The most important use of bamboo is as a raw material in pulp, about 1.9 million tones used by pulp industries. About 4.9 million metric 
tonnes are being presently utilized for paper making (Varmah et al., 1981). In the lives of rural poor and rural industries the bamboos occupy a special place, especially in Asia (Rao et al., 1990). Young new shoots of bamboo are eaten in Asia. In India bamboo is used for making paper, since it provides good quality paper pulp (Mehra et al., 2007). Bamboo can be used as materials for house construction, daily sundry goods, agricultural and fisheries tools, and crafting material (Chang et al., 1997).

It has traditionally been propagated through seed or through vegetative methods but these methods besets with many problems. Conventional methods of propagation are best with problems such as seed sterility, nonavailability of seeds, unpredictable and long flowering cycles and bulkiness of rhizomes (Rao et al., 1990). Rhizome planting, culm cutting and seedling cultivations these are the methods for the multiplication of bamboos (Kumar et al., 1981 and Uchimura, 1990). Therefore, it is imperative by adopting the latest plant biotechnologies, new utilities of bamboos could progress beyond the current level. Tissue culture is one essential technique to micro propagate regenerated plant tissues and it is also for the genetic improvement through the use of different transformation strategies (Kalia et al., 2004; Lin et al., 2003, 2004; Sexena 1990). In this regard, tissue culture techniques offer an alternative method for rapid multiplication of bamboo species and tissue culture extremely useful (Kondas 1982).

The callus culture systems useful for plant improvement, however, it will depend on the ability to regenerate whole plants from callus. In general bamboo has been considered difficult to culture in vitro (Alexander et al., 968) reported aseptic culture of embryos from zygotic embryo culture, while callus cultures derived from the seed, leaves and shoot tips of several species were also produced (Huang and Murashige1983). Regeneration of callus induction from mature seeds was observed in some species of bamboo (Rao et al., 1985; Yeh and Chang 1987).

The potential of micro propagation has raised high hopes and a lot of research has been focused on the development of protocols for rapid and large scale propagation (Rao et al., 1985; Nadgauda et al., 1990; Godbole et al., 2002; Sood et al., 2002). Micro propagation of bamboo species using seed has the advantage of having greater number of genotypes in culture, from where propagation may proceed ensuring greater diversity of the species.

However, micro propagation through auxiliary branching is expensive, and hence not applicable for plant production for forestry and silviculture, especially in rural regions in Asia. Therefore it is desirable to develop methods based on somatic embryogenesis to reduce costs of bamboo liners and planting materials for forestry. Somatic embryogenesis is a promising alternative wherein somatic embryos can be germinated to form plants (Rao et al., 1987., John et al., 1995., Joshi et al., 1997). The first report on SE in bamboo was published almost 25 years ago (Mehta et al., 1982), and since then more than 50 publications have dealt with SE in bamboos.

Thus, somatic embryogenesis can be effectively used for mass propagation of important bamboos. Since, embryogenic calli maintain their regenerative competence for a long time, they can give rise to genetically uniform plantlets (Vasil et al., 1982). The compact organized structures can be visibly screened, multiplied and germinated easily and these add to list of benefits of using somatic embryos. SE serving as a preferred method for rapid in vitro multiplication of 
plants, it also serves as are ideal experimental system for understanding mechanism of differentiation as well as totipotency in plant cells (Arya et al., 2000). It is also serving as ideal explants for carrying out transformation studies and regeneration of transgenic plants.

However, in almost all cases the research has been limited to SE from seeds or seedlings in two species, namely Dendrocalamus strictus and Bambusa bambos, for which seeds are available annually.

In India, Dendrocalamus strictus is the most economically important bamboo species, accounting for $66.6 \%$ of the raw material used for paper production material. Induction of callus is used for indirect somatic embryogenesis. By considering above points the present investigation entitled "In vitro callus induction of green Bamboo" was carried out at MGM College of Agricultural Biotechnology, Gandheli, Aurangabad.

\section{Materials and Methods}

\section{Experimental site}

The research work was carried out in MGM College of Agricultural Biotechnology, Gandheli, Aurangabad.

\section{Experimental Design}

The experimental was laid down in Completely Randomized Design (CRD) With nine treatments of 2,4-D ranging from 0 $\mathrm{mg} / \mathrm{lit}$ to $8 \mathrm{mg} / \mathrm{lit}$ and three replication.

\section{Plant Material}

The most important material to initiate callus is suitable explants. These explants should be obtained from mother plants which are healthy, disease free and age of mother plant should be at least 2 years. Healthy Explants were obtained from the field of Mahatma Gandhi Missions Hills, Gandheli, Aurangabad. However the seeds of green bamboo were purchased from nursery. The mature seed explants of Dendrocalamus strictus variety of bamboo purchased from RK nursery and seeds, $7^{\text {th }}$ street, Shree Ram Nagar, Vadavali Coimbator-641 046.

\section{Sterilization of explant}

The explants sterilization is of at most important to avoid the growth of unwanted microorganism under in vitro condition. These explants were collected from healthy mother plants. Then these explants are washed with RO water to remove dirt. Then the explants were washed with sterile distilled water for three times. After this the explants were transferred in Laminar Air Flow Cabinet for further sterilization. Inside Laminar Air Flow Cabinet these explants were again washed with bavistin for 10 minutes followed by tween -20 for 5 minutes followed by three washes of autoclaved distilled water. After the explants were treated with $70 \%$ ethanol for 30 seconds and then rinsed with sterile distilled water for three times. These explants are suitable for inoculation. (Yuan et.al. 2009)

\section{Media Preparation}

The Murashige and Skoog basal media was prepared by adding various components from stock solution in autoclaved distilled water. The concentration of 2,4- Dichlorophenoxy acetic acid was ranged from 0 to $8 \mathrm{mg} / \mathrm{l}$. These stock of $10 \mathrm{mg} / \mathrm{lit}$ of 2,4-D was prepared by dissolving powder in $1 \mathrm{~N}$ sodium hydroxide. The concentration of Sucrose was $30 \mathrm{gm} / \mathrm{lit}$ and clarigel at concentration of $3 \mathrm{~g} / \mathrm{lit}$ was used for solidification. The $\mathrm{pH}$ of the medium was adjusted to 5.8 before addition of agar. The $40 \mathrm{ml}$ media was poured into each culture bottles. They were then autoclaved at $121^{\circ} \mathrm{C}$ for 20 minutes at $15 \mathrm{psi}$ 
pressure and transferred to culture room where they were kept under dark for 72 hours before inoculation (Murashige and Skoog 1962) (Gillis et al., 2007).

\section{Inoculation of explant callus induction}

Leaf:- The surface sterilized explants of leaf was cut to size of $1 \mathrm{~cm}^{2}$ under Laminar Air Flow Cabinet. Then these explants were damaged by making cuts. Then these explants were transferred on surface of MS media.

Node: The sterilized nodes were further trimmed to reduce its size and nodal section is damaged using blades under LAF cabinet. These explants was transferred to MS media and submerged in it.

Seed: The surface sterilized seeds explants contain seed covering which was removed using forceps. These removals were carried out under LAF cabinet. After removal of seed covering the seeds were transferred to MS media for further incubation. (Lin et.al. 2004)

\section{Culture condition for callus induction}

After inoculation of explants these culture bottles were capped and sealed with parafilm strips. These culture bottles were transferred to culture room. All the cultures were incubated in dark condition in a culture room at $25 \pm 2^{\circ} \mathrm{C}$, with a relative humidity of $50-60$ percent.

\section{Observations and Analysis}

The observation includes number of days required for germination of seeds, Days required for initiation of callus, diameter of callus, nature of callus and colour of callus. The quantitative data obtained on various observations was analyzed by "Analysis of variance (ANOVA)" method (Panse and Sukhatme, 1967).

\section{Results and Discussion}

\section{Surface sterilization}

The surface sterilization of explants is very essential for successful establishment of plant tissue culture. The protocol for surface sterilization was successfully established. Explants are washed with RO water to remove dirt. Then the explants were washed with sterile distilled water for three times. After this the explants were transferred in Laminar Air Flow Cabinet for further sterilization. Inside Laminar Air Flow Cabinet these explants were again washed with bavistin for 10 minutes followed by tween -20 for 5 minutes followed by three washed of autoclaved distilled water. After the explants were treated with $70 \%$ ethanol for 30 seconds and then rinsed with sterile distilled water for three times. It was found that the explants reminded sterile under in vitro condition without any sign of contamination for 21 days.

\section{Suitable explants for callus induction}

Total three different explants were used to initiate the callus culture Viz. Leaf, Node and Seed. It was found that both leaf and node fail to produce the callus under given condition and callus formation was observed from seeds after germination. The reason that leaf and nodal explants fail to form callus is lack of regeneration under provided culture condition. The leaf and nodal explants survived culture condition only up to seven days. After seven days most of them died due to browning. The explants fail to endure sterilization treatment.

\section{Days required for germination}

Data of average number of days required for germination of seeds as influenced by different concentration of growth hormone 
2,4-Dichlorophenoxyacetic acid is given in table 1 .

Data presented in table 2 and depicted in Fig. 1 revealed that the germination of bamboo seeds was influenced by different concentration of 2,4-D. The treatment $\mathrm{T}_{4}$ is significantly superior over $\mathrm{T}_{1}, \mathrm{~T}_{2}, \mathrm{~T}_{3}, \mathrm{~T}_{6}, \mathrm{~T}_{7}$, $\mathrm{T}_{8}$ and $\mathrm{T}_{9}$. Treatment $\mathrm{T}_{4}$ is at par with $\mathrm{T}_{5}$. It was observed that Treatment $T_{5}$ is at par with treatment $\mathrm{T}_{6}, \mathrm{~T}_{3}$ and at par with rest of others. Moreover Treatment $\mathrm{T}_{6}$ is superior over $\mathrm{T}_{8}$, $\mathrm{T}_{9}, \mathrm{~T}_{1}$ and $\mathrm{T}_{2}$. The concentration of 2,4-D
$(3 \mathrm{mg} / \mathrm{lit})$ is most suitable for germination of seeds. But it is also observed that there is breaking of seed dormancy at this concentration and after few days if these are not transferred to light, the shoot fails to grow and forms callus. Hence in vitro germination of seed provide a more aseptic way of forming callus as seed has hard seed coat which can endure harsh sterilization treatment which generally is not tolerated by leaf and nodal explants. The seeds are very attractive source of initiation of callus culture for bamboo.

Table.1 Different concentrations of 2,4-Dichlorophenoxyacetic acid

\begin{tabular}{|l|c|}
\hline Treatments & Concentrations of $\mathbf{2 , 4 - D}$ ( $m g /$ lit $)$ \\
\hline $\mathrm{T}_{0}$ & 0 \\
\hline $\mathrm{T}_{1}$ & 1.0 \\
\hline $\mathrm{T}_{2}$ & 2.0 \\
\hline $\mathrm{T}_{3}$ & 3.0 \\
\hline $\mathrm{T}_{4}$ & 4.0 \\
\hline $\mathrm{T}_{5}$ & 5.0 \\
\hline $\mathrm{T}_{6}$ & 6.0 \\
\hline $\mathrm{T}_{7}$ & 7.0 \\
\hline $\mathrm{T}_{8}$ & 8.0 \\
\hline
\end{tabular}

Table.2 Average number of days required for germination of seeds

\begin{tabular}{|c|c|}
\hline $\begin{array}{c}\text { Treatment } \\
\text { (Concentration of 2,4-D) }\end{array}$ & $\begin{array}{c}\text { Average Number of Days } \\
\text { required for germination } \\
\text { of Seeds }\end{array}$ \\
\hline $\mathbf{T}_{\mathbf{1}}(0.0 \mathrm{mg} / \mathrm{lit})$ & 8.67 \\
\hline $\mathbf{T}_{\mathbf{2}}(1.0 \mathrm{mg} / \mathrm{lit})$ & 8.33 \\
\hline $\mathbf{T}_{\mathbf{3}}(2.0 \mathrm{mg} / \mathrm{lit})$ & 5.67 \\
\hline $\mathbf{T}_{\mathbf{4}}(3.0 \mathrm{mg} / \mathrm{lit})$ & 3.00 \\
\hline $\mathbf{T}_{\mathbf{5}}(4.0 \mathrm{mg} / \mathrm{lit})$ & 3.33 \\
\hline $\mathbf{T}_{\mathbf{6}}(5.0 \mathrm{mg} / \mathrm{lit})$ & 4.67 \\
\hline $\mathbf{T}_{\mathbf{7}}(6.0 \mathrm{mg} / \mathrm{lit})$ & 5.67 \\
\hline $\mathbf{T}_{\mathbf{8}}(7.0 \mathrm{mg} / \mathrm{lit})$ & 6.00 \\
\hline $\mathbf{T}_{\mathbf{9}}(8.0 \mathrm{mg} / \mathrm{lit})$ & 6.33 \\
\hline C.D. $(\mathbf{0 . 0 1})$ & $\mathbf{1 . 4 3 0}$ \\
\hline
\end{tabular}


Table.3 Average number of days required for initiation of callus

\begin{tabular}{|c|c|}
\hline Treatment (Concentration of & $\begin{array}{c}\text { Average Number of Days } \\
\text { required initiation of callus }\end{array}$ \\
\hline 2,4-D) & Fail to initiate callus \\
\hline $\mathbf{T}_{\mathbf{1}}(0.0 \mathrm{mg} / \mathrm{lit})$ & 17.33 \\
\hline $\mathbf{T}_{\mathbf{2}}(1.0 \mathrm{mg} / \mathrm{lit})$ & 17.33 \\
\hline $\mathbf{T}_{\mathbf{3}}(2.0 \mathrm{mg} / \mathrm{lit})$ & 18.00 \\
\hline $\mathbf{T}_{\mathbf{4}}(3.0 \mathrm{mg} / \mathrm{lit})$ & 18.33 \\
\hline $\mathbf{T}_{\mathbf{5}}(4.0 \mathrm{mg} / \mathrm{lit})$ & 22.33 \\
\hline $\mathbf{T}_{\mathbf{6}}(5.0 \mathrm{mg} / \mathrm{lit})$ & 24.33 \\
\hline $\mathbf{T}_{\mathbf{7}}(6.0 \mathrm{mg} / \mathrm{lit})$ & 31.00 \\
\hline $\mathbf{T}_{\mathbf{8}}(7.0 \mathrm{mg} / \mathrm{lit})$ & 30.67 \\
\hline $\mathbf{T}_{\mathbf{9}}(8.0 \mathrm{mg} / \mathrm{lit})$ & $\mathbf{1 . 8 8 5}$ \\
\hline C.D. $(\mathbf{0 . 0 1})$ & \\
\hline
\end{tabular}

Table.4 Diameter of callus

\begin{tabular}{|c|c|}
\hline $\begin{array}{c}\text { Treatment (Concentration of } \\
\text { 2,4-D) }\end{array}$ & $\begin{array}{c}\text { Diameter of callus } \\
(\mathrm{mm})\end{array}$ \\
\hline $\mathbf{T}_{\mathbf{1}}(0.0 \mathrm{mg} / \mathrm{lit})$ & Fail to initiate callus \\
\hline $\mathbf{T}_{\mathbf{2}}(1.0 \mathrm{mg} / \mathrm{lit})$ & 1.00 \\
\hline $\mathbf{T}_{\mathbf{3}}(2.0 \mathrm{mg} / \mathrm{lit})$ & 3.00 \\
\hline $\mathbf{T}_{\mathbf{4}}(3.0 \mathrm{mg} / \mathrm{lit})$ & 1.67 \\
\hline $\mathbf{T}_{\mathbf{5}}(4.0 \mathrm{mg} / \mathrm{lit})$ & 4.00 \\
\hline $\mathbf{T}_{\mathbf{6}}(5.0 \mathrm{mg} / \mathrm{lit})$ & 1.67 \\
\hline $\mathbf{T}_{\mathbf{7}}(6.0 \mathrm{mg} / \mathrm{lit})$ & 1.67 \\
\hline $\mathbf{T}_{\mathbf{8}}(7.0 \mathrm{mg} / \mathrm{lit})$ & 1.33 \\
\hline $\mathbf{T}_{\mathbf{9}}(8.0 \mathrm{mg} / \mathrm{lit})$ & 1.33 \\
\hline C.D. (0.01) & $\mathbf{1 . 0 8 9}$ \\
\hline
\end{tabular}

Fig.1 Effect of different concentration of 2,4-D auxin on seed germination




Fig.2 Number of days required to initiate callus



Fig.3 Effect of different concentration of 2,4-D on callus growth

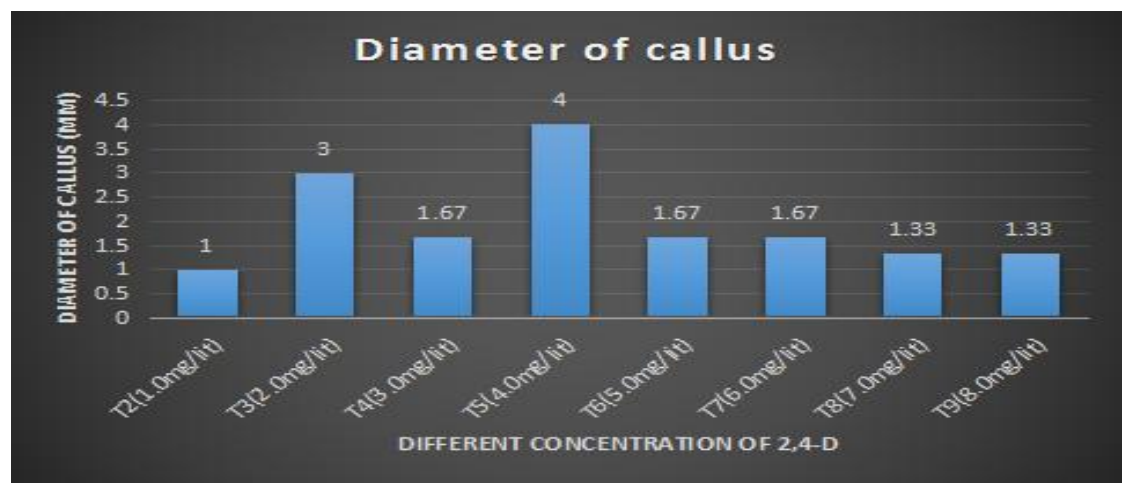

Plate 5 Growth of callus
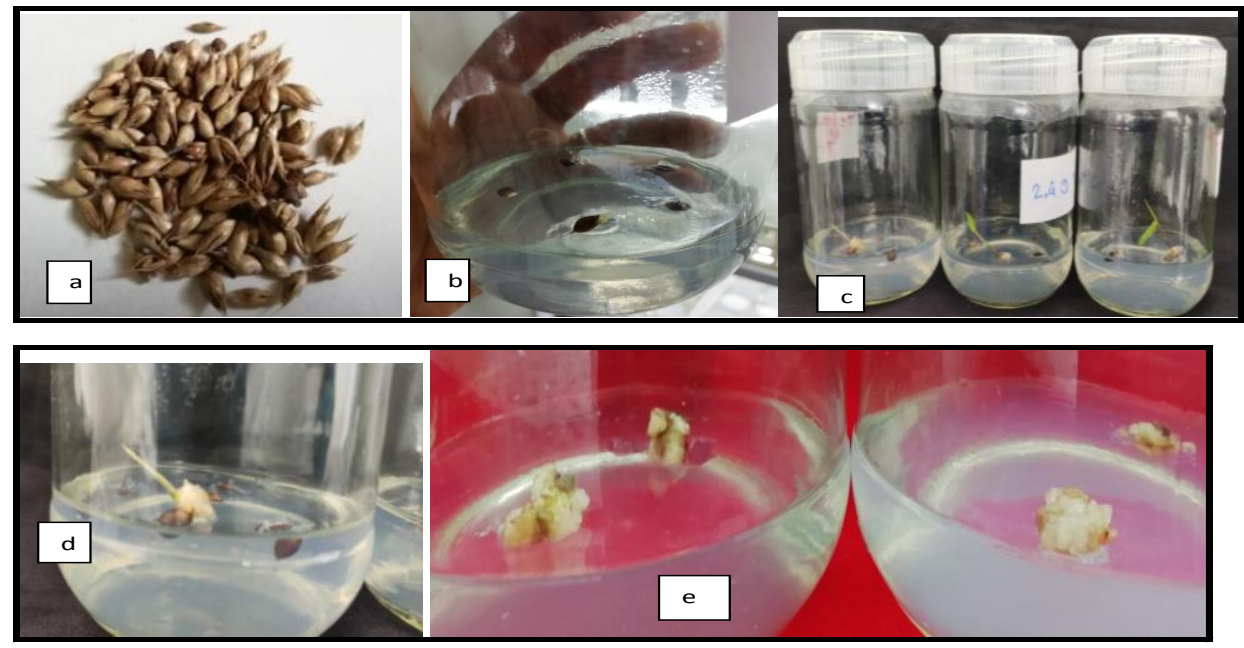

$\mathrm{a}=$ Seed explants of Bamboo (Dendrocalamus strictus) $. b=$ noculation of seed $. c=$ Germination of seed explants $. d=$ callus initiations $. e=$ The friable, light yellow whitish callus 


\section{Days required initiation of callus}

Data of average number of days required for initiation of callus as influenced by different concentration of growth hormone 2,4Dichlorophenoxyacetic acid is given in table 3.

Data presented in table 3 and figure 2 clearly indicates that the initiation of callus from germinated seed is not observed in treatment $\mathrm{T}_{1}$. This indicates that growth hormone is necessary for formation of callus as other treatment successfully initiated callus. The 2,4-dicholorphenoxy acetic acid induce dedifferentiation in cells of explants which form unorganized mass of cells. This unorganized mass grows with each day till supply of sufficient nutrient from media. Treatment $T_{2}, T_{3}, T_{4}$ and $T_{5}$ are at par with each other for initiating callus where as they are superior over rest other treatments. This experiment indicates that concentration of 2,4-D at $1 \mathrm{mg} / \mathrm{lit}, 2 \mathrm{mg} / \mathrm{lit}, 3 \mathrm{mg} / \mathrm{lit}$ is most suitable for inducing callus from seed explant. Whereas other concentrations do induce callusing but they need more time. Callus induction is result of threshold concentration of this growth hormone inside and outside the explant under in vitro condition

\section{Diameter of callus}

Data of average diameter of callus as influenced by different concentration of growth hormone 2,4-Dichlorophenoxyacetic acid is given in table 4 .

Data presented in table 4 and figure 3 shows that the growth of callus is significantly influenced by different concentrations of growth hormone 2,4-D. The diameter of callus is found highest $4 \mathrm{~mm}$ in treatment $T_{5}$ which is significantly superior over rest of others. Moreover the treatments $\mathrm{T}_{3}$ found significantly superior over rest of others except $T_{5}$. All other treatments are at par with each other. It has been observed that there is not specific pattern of callus growth. The growth of callus is due to threshold level of hormones present inside media as well as synthesized by callus itself.

\section{Nature of callus}

The callus produced under in vitro condition is friable and easily breaks. There is no effect of growth hormone concentration of nature of callus. This friable callus can be used for suspension culture. Moreover it can be further used for somatic embryogenesis.

\section{Colour of callus}

The callus when initiated forms completely whitish mass but as it growth continues it turns slightly yellowish. The colour of callus is found to be same in all treatment. Hence it is concluded that the different concentration of growth hormone does not affect colour pattern of callus.

The result obtained in this research work are clearly indicates that 2,4-dichlorophenoxy acetic acid is suitable for induction and growth of callus of bamboo. Similar type of result was obtained by Yuan et al., (2009) in Bambusa multiplex. This callus can be further used for induction of Somatic embryogenesis. Moreover Yeh et al., (1984) also regenerated callus using bamboo explant and utilized it for plant regeneration via somatic embryogenesis. The calli formed is fragile and it represents that the cells are actively growing. The induction of callus formation was also observed under influence of 2,4Dicholophenoxy acetic acid. This hormone increases the rate of cell division in explant. This starts the process of dedifferentiation where unorganized mass of cells start forming under in vitro condition from differentiated explant. This process once started leads to 
formation of calli. Many more researchers' viz. Zhang et al., (2010), Rao et al., (1985), Godbole et al., (2002) etc. Reported callusing induction in different species of bamboo. The produced calli shows whitish mass of cells. These calli when matures leads to yellowish colouration. The growth of callus again starts under influence of growth hormone The fundamental work carried out in this research paper clearly indicated that seed are best source to obtain callus of bamboo which can be further used for somatic embryogenesis.

\section{Acknowledgement}

The authors gratefully acknowledge the Management of Mahatma Gandhi Mission, Aurangabad who permitted to carry out this research work by using all the facilities available at MGM Hills Campus, Gandheli, Aurangabad.

\section{References}

Alexander MP, Rao TC (1968) In vitro culture of bamboo embryos. Curr Sci 37:415.

Anonymous (1978), Bamboo Forest News for Asia and the Pacific, FAO, Bangkok 2, 4.

Arya S, Satsangi R, Arya ID (2008). Large scale plant propagation of edible bamboo Dendrocalamus asper through somatic embryogenesis. J Am Bamb Soc 21: 21-31.

Chambers SM, Heuch JHR, Pirrie A (1991) Micropropagation and in vitro flowering of the bamboo Dendrocalamus hamiltonii Munro. Plant Cell Tiss Organ Cult 27: 45-48.

Chang WC, Ho CW (1997) micropropagation of bamboo. In: Bajaja YSP (ed) Biotechnology in Agriculture and Forestry. High -tech and Micopropagation vol. 39. Springler, Berlin, Heidelberg, New York, pp 221-
237.

Godbole S, Sood A, Thakur R, Sharma M, Ahuja PS (2002) Somatic embryogenesis and its conversion into plantlets in a multipurpose bamboo, Dendrocalamus hamiltonii Nees et Arn. Ex Munro. Curr Sci 83:885-889.

Huang, L. C. and Murashige, T.: Tissue culture investigations of bamboo. I, callus culture of Bambusa, phyllostchys and Sesa. Bot. Bull. Sin (Taipel) 24: 31-52 (1983).

Kondas , S.: Bamboo Biology culm potential and problems of cultivation. The Indian Forester. 108: 179-188 (1982).

Lin CS, Lin CC, Chang WC (2004). Effect of thidiazuron on vegetative tissuederived somatic embryogenesis and flowering of bamboo Bambusa edulis. Plant Cell Tiss Org Cult 76: 758.

Mehta U, Rao IVR, Ram HYM (1982) Somatic embryogenesis in bamboo. In: Proc 5th Intl Cong Plant Tiss and Cell Cult 109-110.

Metha U, Rao R, Ram M (1982) Somatic Embryogenesis in Bamboo. In: 5th Intl Cong Plant Tissue \& Cell Culture, pp 109-110.

Murashige T, Skoog F (1962) A revised medium for rapid growth and bioassays with tobacco tissue cultures. Physiol Plant 15:473-497.

Nadgauda RS, John CK, Joshi MS et al (1997) Application of in vitro techniques for bamboo improvement. In: Chapman (ed) The Bamboos. The Linnean Society of London, pp 163177.

Rao IU, Rao IVR, Narang V (1985) Somatic embryogenesis and regeneration of plants in the bamboo Dendrocalamus strictus. Plant Cell Rep 4:191-194.

Rao IU, Rao IVR, Narang V (1985). Somatic embryogenesis and regeneration of plants in bamboo, Dendrocalamus strictus. Plant Cell Rep 4:191-194. 
Saxena S, Dhawan V (1999) Regeneration and large scale propagation of bamboo (Dendrocalamus strictus Nees) through somatic embryogenesis. Plant Cell Rep 18:438- 443.

The Wealth Of India - Raw materials Vol. 1, Council of Scientific and Industrial Research Delhi, India 145- 154 (1948).

Tsay HS, Yeh CC, Hsu JY (1990) Embryogenesis and plant regeneration from anther culture of bamboo (Sinocalamus latiflora (Munro) McClure). Plant Cell Rep 9:349-351.

Uchimura E (1981) Site condition of growth and methods of multiplication on bamboo. In: Higuchi T (ed) Bamboo Production and Utilization. Proceedings of IUFRO World Congress, Kyoto, 23-26.
Varmah; J. C. and Pant, M M: The Production and Utilization Of Bamboos. The Indian Forester. 107: 465-476 (1981).

Vasil IK (1982). Induction of embryogenic callus culture of Gramineae. In Vasil, I.K. ed. Cell Culture and Somatic Cell Genetics of plants vol.1. Academic Press Inc. Orlando. Florida. pp. 36-41.

Yeh ML, Chang WC (1986) Somatic embryogenesis and subsequent plant regeneration from inflorescence callus of Bambusa beecheyana Munro var. beecheyana. Plant Cell Rep 5:409-411.

Yuan JL, Gu XP, Li LB, Yue JJ, Yao N, et al. (2009) Callus induction and plantlet regeneration of Bambusa multiplex. Scientia Silvae Sinica 45:38-42 (in Chinese).

\section{How to cite this article:}

Mali, A. S., N. S. Chavan and Chavan, N. R. 2020. In vitro Callus Induction of Green Bamboo. Int.J.Curr.Microbiol.App.Sci. 9(10): 683-692. doi: https://doi.org/10.20546/ijcmas.2020.910.082 